\title{
Recent developments in osteogenesis imperfecta [version 1;
}

\section{peer review: 3 approved]}

\author{
Joseph L. Shaker ${ }^{1}$, Carolyne Albert2,3, Jessica Fritz², Gerald Harris²,3
}

${ }^{1}$ Endocrinology, Medical College of Wisconsin, Milwaukee, WI, USA

${ }^{2}$ Orthopaedic and Rehabilitation Engineering Center, Marquette University and Medical College of Wisconsin, Milwaukee, WI, USA

${ }^{3}$ Shriners Hospitals for Children, Chicago, IL, USA

V1 First published: 07 Sep 2015, 4(F1000 Faculty Rev):681

https://doi.org/10.12688/f1000research.6398.1

Latest published: 07 Sep 2015, 4(F1000 Faculty Rev):681

https://doi.org/10.12688/f1000research.6398.1

\section{Abstract}

Osteogenesis imperfecta (OI) is an uncommon genetic bone disease associated with brittle bones and fractures in children and adults. Although OI is most commonly associated with mutations of the genes for type I collagen, many other genes (some associated with type I collagen processing) have now been identified. The genetics of OI and advances in our understanding of the biomechanical properties of OI bone are reviewed in this article. Treatment includes physiotherapy, fall prevention, and sometimes orthopedic procedures. In this brief review, we will also discuss current understanding of pharmacologic therapies for treatment of OI.

Keywords

Osteogenesis imperfecta, mutations, recessive

\section{Open Peer Review \\ Approval Status \\ 12 \\ 3 \\ version 1 \\ 07 Sep 2015 \\ 1. Malachi J. McKenna, St. Vincent's University \\ Hospital, Dublin, Ireland \\ 2. Sudhaker Dhanwada Rao, Henry Ford \\ Hospital, Detroit, USA \\ 3. Bart Clarke, Mayo Clinic College of Medicine, Rochester, USA \\ Any comments on the article can be found at the end of the article.}

Corresponding author: Joseph L. Shaker (joseph.shaker@froedtert.com)

Competing interests: JS is a consultant for Alexion Pharmaceuticals. The other authors declare that they have no competing interests. Grant information: The author(s) declared that no grants were involved in supporting this work.

Copyright: @ 2015 Shaker JL et al. This is an open access article distributed under the terms of the Creative Commons Attribution License, which permits unrestricted use, distribution, and reproduction in any medium, provided the original work is properly cited.

How to cite this article: Shaker JL, Albert C, Fritz J and Harris G. Recent developments in osteogenesis imperfecta [version 1; peer review: 3 approved] F1000Research 2015, 4(F1000 Faculty Rev):681 https://doi.org/10.12688/f1000research.6398.1

First published: 07 Sep 2015, 4(F1000 Faculty Rev):681 https://doi.org/10.12688/f1000research.6398.1 


\section{Introduction}

Osteogenesis imperfecta (OI) is an unusual heritable disease that occurs in about 1 in 10,000 to 20,000 live births ${ }^{1}$. The major clinical manifestation is skeletal fragility. Skeletal deformity, joint laxity, and scoliosis may be present ${ }^{2}$. Other extraskeletal manifestations include hearing loss, dentinogenesis imperfecta, blue/gray sclerae, hypercalciuria, aortic root dilatation, and neurologic conditions such as macrocephaly, hydrocephalus, and basilar invagination ${ }^{1-5}$. The phenotype is variable, ranging from osteoporosis presenting in adulthood to lethality in children ${ }^{3}$. Even adults with "mild" OI may have significant musculoskeletal symptoms, including arthritis, fractures, back pain, scoliosis, and tendon ruptures ${ }^{6}$.

About $90 \%$ of patients have mutations in type I collagen genes (COL1A1 and COL1A2) 3 ; however, many other genes have now been described. Some of the genes encode proteins related to type I collagen (for example, enzymes that modify type I collagen, chaperone proteins, and signaling proteins). In 1979, Sillence et al. proposed a classification system for OI with four types based on severity: type I mild non-deforming, type II perinatal lethal, type III severely deforming, and type IV moderately deforming? This classification has been expanded as new genes were discovered. Phenotypic classification (types I to V with multiple genes included in some of the types) has been proposed ${ }^{5}$. Alternatively, classification by genetics has been proposed (see Table 1), which was created through modifications of references ${ }^{8-10}$.

There have been recent advances in the understanding of the structure and mechanical properties of bone in children with OI. These advances may lead to improved finite element (FE) models that help predict fracture risk of specific activities and help plan physiotherapy.

In addition to physiotherapy and orthopedic surgery when needed, intravenous bisphosphonates have been used extensively in moderate to severe OI in childhood. Less is known about pharmacologic treatment in adults. Anabolic therapy with PTH 1-34 has been studied in adults with OI. Future therapies may include antibodies to sclerostin, transforming growth factor beta (TGF $\beta$ ) antagonism, gene therapy, and cell-based therapies.

\section{Genes and classification}

$\mathrm{OI}$ is most commonly caused by mutations in type I collagen. Type I collagen is a rod-like structure formed from a trimer of 2 COL1A1 and 1 COL1A2 subunits ${ }^{3}$, which requires post-translational modification. Many of the other rare forms of OI are due to defects in

Table 1. Classification of osteogenesis imperfecta.

\begin{tabular}{|c|c|c|c|c|c|}
\hline Type & Inheritance & Gene & Protein & Defect & Phenotype \\
\hline I & $A D$ & COLA1/COLA2 & $\alpha 1(1)$ collagen & Collagen quantity & Mild, non-deforming \\
\hline II & $A D$ & COLA1/COLA2 & $\alpha 1(1) / \alpha 2(1)$ collagen & Collagen structure & Perinatal lethal \\
\hline III & $A D$ & COLA1/COLA2 & $\alpha 1(1) / \alpha 2(1)$ collagen & Collagen structure & Progressively deforming \\
\hline IV & $A D$ & COLA1/COLA2 & $\alpha 1(1) / \alpha 2(1)$ collagen & Collagen structure & Moderately deforming \\
\hline V & $A D$ & IFITM5 & BRIL & Matrix mineralization & $\begin{array}{l}\text { Moderate, distinct } \\
\text { histology }\end{array}$ \\
\hline $\mathrm{VI}$ & AR & SERPINF1 & PEDF & & $\begin{array}{l}\text { Moderate to severe, } \\
\text { distinct histology }\end{array}$ \\
\hline VII & AR & CRTAP & CRTAP & Prolyl 3 hydroxylation & Severe to lethal \\
\hline VIII & AR & LEPRE1 & $\mathrm{P} 3 \mathrm{H} 1$ & Prolyl 3 hydroxylation & Severe to lethal \\
\hline IX & AR & PPIB & CyPB & Prolyl 3 hydroxylation & Moderate to lethal \\
\hline$x$ & AR & SERPINH1 & HSP47 & Collagen chaperoning & Severe \\
\hline$X I$ & AR & FKBP10 & FKBP65 & Telopeptide hydroxylation & $\begin{array}{l}\text { Progressively deforming } \\
\text { (Bruck syndrome) }\end{array}$ \\
\hline XII & $\mathrm{AR}$ & SP7 & SP7/osterix & Osteoblast development & Moderate \\
\hline XIII & AR & $B M P 1$ & BMP1/mTLD & Collagen processing & Severe, high bone mass \\
\hline XIV & AR & TMEM38B & TRIC-B & Cation channel defect & Moderate to severe \\
\hline$X V$ & AR & WNT1 & WNT1 & & Variable \\
\hline$X V$ & $A D$ & WNT1 & WNT1 & & Early-onset osteoporosis \\
\hline \multicolumn{6}{|c|}{ Others } \\
\hline & AR & CREB3L 1 & Oasis & COL1A1 transcription & Progressively deforming \\
\hline & $X L$ & PLS3 & Plastin & Osteocyte defect & Mild \\
\hline & AR & PLOD2 & Lysyl hydroxylase 2 & $\begin{array}{l}\text { Collagen telopeptide } \\
\text { hydroxylation }\end{array}$ & Progressively deforming \\
\hline
\end{tabular}

$A D$, autosomal dominant; $A R$, autosomal recessive; $X L, x$-linked. 
proteins involved in cross-linking, hydroxylation, and mineralization of type I collagen.

Mutations of CRTAP, which encodes cartilage-associated protein, have been shown to cause recessive $\mathrm{OI}^{1-14}$. Mutations of LEPRE1, which encodes prolyl 3 hydroxylase ${ }^{14-16}$, and PPIB (protein cyclophylin B) ${ }^{17-19}$ also cause recessive OI. The proteins described above form a complex that modifies specific prolines in the collagen and these mutations result in moderate to lethal OI.

SERPINH1 mutations cause severe recessive $\mathrm{OI}^{20}$. The protein affected in SERPINH1 mutations, HSP47, is a collagen chaperone protein $^{8}$. FKBP10 mutations cause recessive OI (progressively deforming $)^{21}$. This gene encodes the protein FKBP65, which appears to be needed for hydroxylation of collagen telopetide lysine $^{22}$. Both HSP47 and FKBP65 are needed for the proper folding of the collagen triple helix. Furthermore, Bruck syndrome (OI and congenital contractures) can be caused by homozygous mutations on FKPB $10^{23}$, and Kuskokwim syndrome (congenital contractures with mild skeletal problems seen in Yup'ik people in Alaska) is caused by FKBP10 mutations ${ }^{24}$. PLOD2 mutations also cause recessive $\mathrm{OI}^{25}$. PLOD-2 encodes lysyl hydroxylase 2, which hydroxylates collagen telopeptide lysine. Bruck syndrome can also be caused by homozygous mutations of PLOD2 $2^{25}$.

BMP1 (bone morphogenetic protein 1) mutations also cause recessive $\mathrm{OI}^{26,27}$. The protein, $\mathrm{BMP} 1$, is a protease that cleaves the c-propeptide of type I collagen ${ }^{26,27}$ but also has other substrates. $S P 7$ mutations cause recessive $\mathrm{OI}^{28}$. SP7 encodes the protein osterix, which may be needed for osteoblast differentiation ${ }^{10}$. WNTI mutations ${ }^{29-31}$ have been reported in early-onset osteoporosis (dominant) and OI (recessive). The protein, WNT1, may be important in the beta catenin system, which stimulates bone formation ${ }^{29-31}$.

TMEM38B mutations have been reported in recessive $\mathrm{OI}^{32}$. This gene encodes TRIC-B, which may be important in intracellular calcium signaling. Defective TRIC-B may cause bone disease through defective calcium signaling in bone cells ${ }^{10}$. CREB3L1 mutations cause recessive $\mathrm{OI}^{33}$. CREB3L1 encodes the protein OASIS, which may activate transcription of COL1A1 ${ }^{34}$. PLS3 (plastin 3) mutations have been reported in $\mathrm{x}$-linked osteoporosis ${ }^{35-37}$. Plastin 3 is expressed in osteocyte dendrites and may be important in mechanosensing ${ }^{35}$. Bone biopsies from patients with PLS3 mutations have shown cortical and trabecular osteoporosis with normal to low bone formation rates ${ }^{36,37}$. There is no mineralization defect ${ }^{36,37}$.

Mutations in IFITM5, a bone-restricted IFITM-like protein (BRIL) (dominant) cause type $\mathrm{V} \mathrm{OI}^{38-42}$. These patients have prominent callus formation and ossification of the forearm interosseous membrane $^{38-42}$. They also have mesh-like lamellation on bone biopsy as well as a mineralization defect ${ }^{38-42}$. There appear to be substantial differences in phenotypic presentation even with similar mutations $^{40-42}$. Type VI OI is caused by mutations in SERPINF1 (protein PEDF) ${ }^{43,44}$. Children with type VI OI have elevated alkaline phosphatase, and bone biopsy reveals fish-scale pattern under polarized light as well as broad bands of unmineralized osteoid ${ }^{43,44}$. Interestingly, some patients with BRIL mutations have phenotypic type VI
OI (rather than type V) ${ }^{45}$. BRIL and PEDF are related, and it appears that mutations causing gain-of-function of BRIL cause OI type $\mathrm{V}$ and that those causing loss-of-function of BRIL look phenotypically like OI type $\mathrm{VI}^{46}$.

\section{Structure and mechanical properties of bones in osteogenesis imperfecta}

From a mechanical perspective, increased fracture risk in individuals with OI could stem from a combination of reduced bone mass, decreased bone material quality, and, in some individuals, the presence of bone deformity.

\section{Bone mass}

Low bone mass is a clinical characteristic of OI, and individuals with this disorder tend to have markedly reduced areal bone mineral density $(\mathrm{BMD})^{47-49}$. This reduced bone mass can be the consequence of decreased bone size or decreased volumetric BMD or both $^{49,50}$. Studies of iliac crest biopsies have revealed lower bone tissue quantity in children with moderate and severe OI, including reduced bone volume fraction, and decreased trabecular and cortical thicknesses ${ }^{51-53}$. Decreased bone volume, though less marked, was also noted in some children with mild $\mathrm{OI}^{51,52}$.

In cortical bone specimens from the long bone shafts of children with OI, "atypical, flattened, and large resorption lacunae" ${ }^{54}$ and abnormally elevated porosity have been observed ${ }^{54-57}$. For example, an average intracortical vascular porosity of $21 \%$ was found in bone shaft osteotomies from children with OI by synchrotron radiation micro-computed tomography ${ }^{55,57}$; the corresponding value in normal pediatric bones was $3 \%{ }^{57}$. From a structural perspective, reduced bone mass can lead to increased stresses within the bone as a result of a smaller area of bone tissue present to support physiological loads. For this reason, low bone mass is likely a considerable contributor to bone fragility in OI.

\section{Bone material quality}

In addition to the structural deficiency (low bone mass), mechanical quality of the bone material in OI is reduced. The genetic defects causing OI affect type I collagen, the main organic component of bone. As discussed earlier, most forms of OI (types I to IV) are attributed to insufficient collagen production or amino acid substitution defects within the collagen molecules or both ${ }^{58-63}$, and less common recessive forms have been associated with abnormalities in other proteins that interact with type I collagen ${ }^{9,64}$. Since type I collagen is an integral component of bone tissues, it should be no surprise that abnormalities affecting this protein would impact bone material quality. At the ultrastructural level, irregularities in collagen and mineral geometry as well as abnormalities in mineral composition have been reported ${ }^{65-70}$. Studies in mice indicated that the material abnormalities in OI have a negative impact on bone material properties $^{71-76}$. A few studies have also used biopsy and osteotomy specimens to measure bone material properties in humans with this disorder. Some of these studies used nanoindentation, a technique in which a diamond-tip indenter is pressed into the polished surface of a material (in this case, bone), creating an indent a few microns in size. With this test, elastic modulus and hardness-that is, properties representing the material's resistance to elastic (recoverable) 
and plastic (non-recoverable) deformation, respectively-are determined at the submicrostructural level. Based on nanoindentation, slightly higher elastic modulus and hardness were found in children with mild (type I) versus severe (type III) $\mathrm{OI}^{77}$, whereas these properties were not found to differ between children with severe (type III) versus moderately severe (type IV) phenotypes ${ }^{78}$. However, exactly how these properties compare with normal tissues remains unclear; one study reported higher elastic modulus and hardness in children with severe OI versus controls ${ }^{79}$, whereas another reported the opposite ${ }^{80}$. Furthermore, bone tissues have a complex hierarchical structure, which results in properties that differ between length scales, and nanoindentation provides only limited insight regarding bone tissue properties at the submicrostructural scale. Another limitation with this technique is that it does not measure strength, a property representing the ability of a material to carry stress without breaking or sustaining damage.

Recent studies have measured cortical bone material properties, including strength, at a larger scale by using surgical bone specimens from long bone diaphyses of children with $\mathrm{OI}^{55,56,81}$. In these studies, small osteotomy specimens were machined into parallelepipedshaped specimens and loaded to failure in either bending ${ }^{55,81}$ or compression $^{56}$. Bone material strength was confirmed to be lower than normal in these children, and this property was found to be negatively related to an abnormally elevated intracortical porosity. These findings suggest that increased cortical porosity contributes to increased risk of long bone fractures in OI.

\section{Bone deformity}

In addition to decreased bone mass and reduced bone material quality (low bone material strength), deformities of the spine and long bones are common in OI. For example, children with severe OI often exhibit anterolateral bowing of the femur and anterior bowing of the tibia ${ }^{7,47}$. Increased curvature in long bones leads to an increase in maximum stresses within the bone shaft ${ }^{82}$. The increased stresses attributed to bone deformities in OI can further contribute to the risk of bone fracture.

\section{Fracture prediction based on mechanical models}

Mechanical modeling through the use of FE analysis is a wellestablished technique that allows detailed analysis of composite structures under a variety of load conditions. In the field of orthopedic biomechanics, FE modeling is frequently used to examine the responses of bone to loading ${ }^{83-86}$. Patient-specific FE models have been effective for bone strain and fracture strength assessment, and as recently as 2009 Fritz et al. applied these models to predict fractures in $\mathrm{OI}^{87,88}$. A femoral model including muscle forces was analyzed during all seven phases of the gait cycle and geometrically matched to bone anatomy with $\mathrm{x}$-rays. The most current work includes advanced meshing techniques for improved geometric biofidelity and updated mechanical property data ${ }^{55}$. Other FE models for assessing OI bones have also been reported. Orwoll et al. used FE modeling to estimate vertebral strength in a study of the effects of teriparatide treatment in adults with $\mathrm{OI}^{89}$. Caouette et al. developed an FE model to assess fracture risk at the tibia in children with $\mathrm{OI}^{90}$. This tibia model examined fracture risk during two-legged hopping, lateral loading, and torsional loading. Future applications of FE modeling may prove invaluable for better quantification of fracture risk in OI. These models could help identify activities that pose greater risk of fracture and, through appropriate controls, may enable persons with OI to participate safely and more fully in a greater spectrum of daily and recreational activities.

\section{Management}

\section{Physical therapy}

The goals of the treatment in OI are to decrease pain and fractures and to maximize mobility. Physical therapy/rehabilitation ${ }^{91}$ is particularly important in children to improve weight bearing and prevent fractures as well as to increase strength and mobility during fracture recovery. Some children may require wheelchairs or walking aids. Occupational therapy may be needed to help with daily living activities.

\section{Pharmacologic therapy}

\section{Bisphosphonates}

Bisphosphonates (BPs) are non-hydrolysable synthetic analogs of pyrophosphate $^{92}$. BPs adhere to mineralized surfaces, inhibit osteoclastic bone resorption, and have very long skeletal half-lives ${ }^{92}$. Intravenous BPs are currently the primary treatment of children with moderate to severe OI. BPs increase BMD and size in children with $\mathrm{OI}^{49}$. BPs do not appear to impair bone formation that increases cortical width in children with $\mathrm{OI}^{93}$. Observational studies suggest decreased fractures ${ }^{94,95}$, decreased bone pain, and improved vertebral shape $\mathrm{e}^{94,95}$. Ability to perform activities of daily living may also be improved. However, it has been difficult to confirm all of these benefits in randomized trials, and the optimal duration of BP treatment is unknown.

In a study of children with predominantly mild OI, oral risedronate increased BMD and appeared to decrease clinical fractures ${ }^{96}$. Atypical fractures have been reported in children with OI treated with bisphosphonates ${ }^{97,98}$; however, osteneocrosis of the jaw does not appear to be a major problem in children with OI treated with BPs ${ }^{9-101}$. Several studies have been done on the use of intravenous or oral BPs in adults with OI. Although BMD increases have been reported during these treatments, fracture data are equivocal ${ }^{102-106}$. A Cochrane review found increased BMD in patients with OI treated with BPs but did not find definitive evidence of fracture reduction ${ }^{107}$. Furthermore, a recent meta-analysis of placebocontrolled trials suggested that the effects of BPs for fracture prevention in OI were inconclusive ${ }^{108}$.

\section{Growth hormone}

Growth hormone has anabolic effects on bone. A 1-year randomized trial of the BP, neridronate, with or without growth hormone showed greater increase in BMD and growth velocity with growth hormone, but there was no fracture benefit of growth hormone ${ }^{109}$.

\section{Teriparatide}

Teriparatide (PTH1-34) is an anabolic agent that stimulates bone formation (and ultimately bone resorption). This drug decreases vertebral and non-vertebral fractures in post-menopausal women 
with osteoporosis ${ }^{110}$. Observational data in adults with OI suggest increased BMD with teriparatide ${ }^{107,111}$. Recently, a randomized trial of teriparatide in adults with OI showed increased BMD as well as increased vertebral strength estimated by FE analysis ${ }^{91}$. The benefits appeared to occur in mild (type I) OI but not in more severe OI (types III and IV).

\section{Denosumab}

Denosumab is a monoclonal antibody to receptor activator of nuclear factor kappa B ligand that decreases bone resorption, increases bone density, and reduces fractures in women with postmenopausal osteoporosis ${ }^{112}$. This drug may represent a future therapy in OI. In a study of four children with type VI OI, increased BMD and mobility and improved vertebral shape were reported after denosumab treatment, and the outcomes of this study indicated that this treatment appears to be safe ${ }^{113}$. There is also a report of denosumab use in two children with OI caused by COL1A1/A2 mutations ${ }^{114}$. As with BPs, "zebra lines" were present, suggesting continued longitudinal growth ${ }^{114}$. Denosumab has been reported to cause hypophosphatemia, hypocalcemia, and secondary hyperparathyroidism in a child with fibrous dysplasia of bone ${ }^{115}$. There was rebound hypercalcemia after stopping denosumab ${ }^{115}$.

\section{Possible future therapies}

Sclerostin is an inhibitor of the LRP5/WnT system that decreases bone formation. Antibodies to sclerostin are in clinical trials for treatment of osteoporosis with the goal to increase bone density ${ }^{116}$. Sclerostin antibody appeared to be effective in a mouse model of moderately severe $\mathrm{OI}^{117,118}$ but less so in a mouse model of more severe $\mathrm{OI}^{119}$. TGF $\beta$ is secreted by osteoblasts and increases osteoclastic bone resorption ${ }^{120}$. Excessive TGF $\beta$ signaling may be important in some forms of OI, and anti-TGF $\beta$ therapy represents an interesting prospect for the future treatment of $\mathrm{OI}^{120}$.
Cell-based therapy, such as bone marrow ${ }^{121}$ or mesenchymal stem cell $^{122-124}$ transplantation, has also been investigated and may have promise; but these could also have significant risks. Gene therapy with allele-specific silencing may represent a future therapy ${ }^{125}$.

\section{Summary}

Although most cases of OI are caused by COL1A1/A2 mutations, many new genetic causes have been identified in recent years. Some of these genes are related to the processing of type I collagen. Furthermore, we have greater understanding of the biomechanics of OI bone, including material properties, muscle and gait load effects, and fracture strength assessment. Biomechanical models could help identify activities that pose greater risk of fracture and, through appropriate controls, may enable persons with OI to participate safely and more fully in a greater spectrum of activities. Physical therapy is an important part of the management of these patients. Intravenous BPs are commonly used in children with moderate to severe OI. Some of the benefits seen in observational studies have been hard to prove in controlled studies. Treatment of adults with OI is less well studied. BPs and teriparatide appear to increase BMD, but fracture data are lacking. Teriparatide appears to increase bone strength as estimated by FE analysis in adults with mild OI. Other promising treatments for OI are under investigation.

\section{Competing interests}

JS is a consultant for Alexion Pharmaceuticals. The other authors declare that they have no competing interests.

\section{Grant information}

The author(s) declared that no grants were involved in supporting this work.
1. Monti $\mathrm{E}$, Mottes $\mathrm{M}$, Fraschini $\mathrm{P}$, et al.: Current and emerging treatments for the management of osteogenesis imperfecta. Ther Clin Risk Manag. 2010; 6 : $367-81$.

PubMed Abstract | Publisher Full Text | Free Full Text

2. Arponen $\mathrm{H}$, Mäkitie $\mathrm{O}$, Waltimo-Sirén J: Association between joint hypermobility, scoliosis, and cranial base anomalies in paediatric Osteogenesis imperfecta patients: a retrospective cross-sectional study. BMC Musculoskelet Disord. 2014; 15: 428

PubMed Abstract | Publisher Full Text | Free Full Text

3. Lindahl $\mathrm{K}$, Langdahl B, Ljunggren Ö, et al.: Treatment of osteogenesis imperfecta in adults. Eur J Endocrinol. 2014; 171(2): R79-90.

PubMed Abstract | Publisher Full Text

4. Lamanna A, Fayers $\mathrm{T}$, Clarke $\mathrm{S}$, et al.: Valvular and aortic diseases in osteogenesis imperfecta. Heart Lung Circ. 2013; 22(10): 801-10. PubMed Abstract | Publisher Full Text

5. Biggin A, Munns CF: Osteogenesis imperfecta: diagnosis and treatment. Curr Osteoporos Rep. 2014; 12(3): 279-88. PubMed Abstract | Publisher Full Text

6. McKiernan FE: Musculoskeletal manifestations of mild osteogenesis imperfecta in the adult. Osteoporos Int. 2005; 16(12): 1698-702. PubMed Abstract | Publisher Full Text

7. Sillence DO, Senn A, Danks DM: Genetic heterogeneity in osteogenesis imperfecta. J Med Genet. 1979; 16(2): 101-16. PubMed Abstract | Publisher Full Text | Free Full Text
8. Valadares ER, Carneiro TB, Santos $\mathrm{PM}$, et al: What is new in genetics and osteogenesis imperfecta classification? J Pediatr (Rio J). 2014; 90(6): 536-41. PubMed Abstract | Publisher Full Text

9. Forlino A, Cabral WA, Barnes AM, et al.: New perspectives on osteogenesis imperfecta. Nat Rev Endocrinol. 2011; 7(9): 540-57. PubMed Abstract | Publisher Full Text | Free Full Text

10. Marini JC, Reich A, Smith SM: Osteogenesis imperfecta due to mutations in non-collagenous genes: lessons in the biology of bone formation. Curr Opin Pediatr. 2014; 26(4): 500-7. PubMed Abstract | Publisher Full Text | Free Full Text

11. F Barnes AM, Chang W, Morello R, et al.: Deficiency of cartilage-associated protein in recessive lethal osteogenesis imperfecta. $N$ Engl J Med. 2006; 355(26): 2757-64

PubMed Abstract | Publisher Full Text | F1000 Recommendation

12. F Morello R, Bertin TK, Chen $\mathrm{Y}$, et al:: CRTAP is required for prolyl 3- hydroxylation and mutations cause recessive osteogenesis imperfecta. Cell. 2006; 127(2): 291-304. PublMed Abstract | Publisher Full Text | F1000 Recommendation

13. Baldridge D, Schwarze U, Morello R, et al:: CRTAP and LEPRE1 mutations in recessive osteogenesis imperfecta. Hum Mutat. 2008; 29(12): 1435-42. PubMed Abstract | Publisher Full Text | Free Full Text

14. Marini JC, Cabral WA, Barnes AM: Null mutations in LEPRE1 and CRTAP cause severe recessive osteogenesis imperfecta. Cell Tissue Res. 2010; 339(1): 59-70. PubMed Abstract | Publisher Full Text | Free Full Text 
15. Pepin MG, Schwarze U, Singh V, et al:: Allelic background of LEPRE1 mutations that cause recessive forms of osteogenesis imperfecta in different populations. Mol Genet Genomic Med. 2013; 1(4): 194-205. PubMed Abstract | Publisher Full Text | Free Full Text

16. F Cabral WA, Chang W, Barnes AM, et al.: Prolyl 3-hydroxylase 1 deficiency causes a recessive metabolic bone disorder resembling lethal/severe osteogenesis imperfecta. Nat Genet. 2007; 39(3): 359-65. PubMed Abstract | Publisher Full Text | F1000 Recommendation

17. van Dijk FS, Nesbitt IM, Zwikstra EH, et al.: PPIB mutations cause severe osteogenesis imperfecta. Am J Hum Genet. 2009; 85(4): 521-7. PubMed Abstract | Publisher Full Text | Free Full Text

18. Barnes AM, Carter EM, Cabral WA, et al:: Lack of cyclophilin B in osteogenesis imperfecta with normal collagen folding. N Engl J Med. 2010; 362(6): 521-8. PubMed Abstract | Publisher Full Text | Free Full Text

19. Pyott SM, Schwarze U, Christiansen HE, et al:: Mutations in PPIB (cyclophilin B) delay type I procollagen chain association and result in perinatal lethal to moderate osteogenesis imperfecta phenotypes. Hum Mol Genet. 2011; 20(8): $1595-609$

PubMed Abstract | Publisher Full Text | Free Full Text

20. F Christiansen HE, Schwarze U, Pyott SM, et al:: Homozygosity for a missense mutation in SERPINH1, which encodes the collagen chaperone protein HSP47, results in severe recessive osteogenesis imperfecta. Am J Hum Genet. 2010; 86(3): 389-98.

PubMed Abstract | Publisher Full Text | Free Full Text | F1000 Recommendation

21. F Alanay $\mathrm{Y}$, Avaygan $\mathrm{H}$, Camacho $\mathrm{N}$, et al.: Mutations in the gene encoding the RER protein FKBP65 cause autosomal-recessive osteogenesis imperfecta. Am J Hum Genet. 2010; 86(4): 551-9.

PubMed Abstract | Publisher Full Text | Free Full Text | F1000 Recommendation

22. Barnes AM, Cabral WA, Weis M, et al:: Absence of FKBP10 in recessive type $\mathrm{XI}$ osteogenesis imperfecta leads to diminished collagen cross-linking and reduced collagen deposition in extracellular matrix. Hum Mutat. 2012; 33(11): 1589-98.

PubMed Abstract | Publisher Full Text | Free Full Text

23. Kelley $\mathrm{BP}$, Malfait $\mathrm{F}$, Bonafe $\mathrm{L}$, et al.: Mutations in FKBP10 cause recessive osteogenesis imperfecta and Bruck syndrome. J Bone Miner Res. 2011; 26(3): 666-72.

PubMed Abstract | Publisher Full Text | Free Full Text

24. Barnes AM, Duncan G, Weis M, et al:: Kuskokwim syndrome, a recessive congenital contracture disorder, extends the phenotype of FKBP10 mutations. Hum Mutat. 2013; 34(9): 1279-88.

PubMed Abstract | Publisher Full Text | Free Full Text

25. Puig-Hervás MT, Temtamy S, Aglan M, et al:: Mutations in PLOD2 cause autosomal-recessive connective tissue disorders within the Bruck syndrome--osteogenesis imperfecta phenotypic spectrum. Hum Mutat. 2012; 33(10): 1444-9.

PubMed Abstract | Publisher Full Tex

26. F Martínez-Glez V, Valencia M, Caparrós-Martín JA et al: Identification of a mutation causing deficient BMP1/mTLD proteolytic activity in autosomal recessive osteogenesis imperfecta. Hum Mutat. 2012; 33(2): 343-50. PubMed Abstract | Publisher Full Text | Free Full Text | F1000 Recommendation

27. Valencia M, Caparrós-Martin JA, Sirerol-Piquer MS, et al.: Report of a newly identified patient with mutations in BMP1 and underlying pathogenetic aspects. Am J Med Genet A. 2014; 164A(5): 1143-50. PubMed Abstract | Publisher Full Text

28. F Lapunzina P, Aglan M, Temtamy S, et al:: Identification of a frameshift mutation in Osterix in a patient with recessive osteogenesis imperfecta. Am J Hum Genet. 2010; 87(1): 110-4.

PubMed Abstract | Publisher Full Text | Free Full Text | F1000 Recommendation

29. F Keupp K, Beleggia $\mathrm{F}$, Kayserili $\mathrm{H}$, et al.: Mutations in WNT1 cause different forms of bone fragility. Am J Hum Genet. 2013; 92(4): 565-74. PubMed Abstract | Publisher Full Text | Free Full Text | F1000 Recommendation

30. F Pyott SM, Tran TT, Leistritz DF, et al.: WNT1 mutations in families affected by moderately severe and progressive recessive osteogenesis imperfecta. Am J Hum Genet. 2013; 92(4): 590-7.

PubMed Abstract | Publisher Full Text | Free Full Text | F1000 Recommendation

31. F Laine CM, Joeng KS, Campeau PM, et al:: WNT1 mutations in early-onset osteoporosis and osteogenesis imperfecta. N Engl J Med. 2013; 368(19): 1809-16.

PubMed Abstract | Publisher Full Text | Free Full Text | F1000 Recommendation

32. F Shaheen R, Alazami AM, Alshammari MJ, et al.: Study of autosomal recessive osteogenesis imperfecta in Arabia reveals a novel locus defined by TMEM38B mutation. J Med Genet. 2012; 49(10): 630-5.

PubMed Abstract | Publisher Full Text | F1000 Recommendation

33. Symoens S, Malfait F, D'hondt S, et al.: Deficiency for the ER-stress transducer OASIS causes severe recessive osteogenesis imperfecta in humans. Orphanet J Rare Diss. 2013; 8: 154

PubMed Abstract | Publisher Full Text | Free Full Text

34. F Murakami T, Saito A, Hino S, et al:: Signalling mediated by the endoplasmic reticulum stress transducer OASIS is involved in bone formation. Nat cell biol. 2009; 11(10): 1205-11.

PubMed Abstract | Publisher Full Text | F1000 Recommendation
35. F van Dijk FS, Zillikens MC, Micha D, et al.: PLS3 mutations in X-linked osteoporosis with fractures. N Engl J Med. 2013; 369(16): 1529-36. PubMed Abstract | Publisher Full Text | F1000 Recommendation

36. Fahiminiya S, Majewski J, Al-Jallad $\mathrm{H}$, et al:: Osteoporosis caused by mutations in PLS3: clinical and bone tissue characteristics. J Bone Miner Res. 2014; 29(8): 1805-14.

PubMed Abstract | Publisher Full Text

37. Laine CM, Wessman M, Toiviainen-Salo S, et al:: A novel splice mutation in PLS3 causes X-linked early onset low-turnover osteoporosis. J Bone Miner Res. 2015; 30(3): 510-8

PubMed Abstract | Publisher Full Text

38. F Cho TJ, Lee KE, Lee SK: A single recurrent mutation in the 5'-UTR of IFITM5 causes osteogenesis imperfecta type V. Am J Hum Genet. 2012; 91(2): 343-8.

PubMed Abstract | Publisher Full Text | Free Full Text | F1000 Recommendation

39. F Semler O, Garbes L, Keupp K, et al:: A mutation in the 5'-UTR of IFITM5 creates an in-frame start codon and causes autosomal-dominant osteogenesis imperfecta type $\mathbf{V}$ with hyperplastic callus. Am J Hum Genet. 2012; 91(2): 349-57.

PublMed Abstract | Publisher Full Text | Free Full Text | F1000 Recommendation

40. Grover M, Campeau PM, Lietman CD, et al:: Osteogenesis imperfecta without features of type $\mathrm{V}$ caused by a mutation in the IFITM5 gene. J Bone Miner Res. 2013; 28(11): 2333-7.

PubMed Abstract | Publisher Full Text | Free Full Text

41. F Shapiro JR, Lietman C, Grover M, et al.: Phenotypic variability of osteogenesis imperfecta type V caused by an IFITM5 mutation. J Bone Miner Res. 2013; 28(7): 1523-30.

PubMed Abstract | Publisher Full Text | Free Full Text | F1000 Recommendation

42. $\mathrm{F}$ Rauch $\mathrm{F}$, Moffatt $\mathrm{P}$, Cheung $\mathrm{M}$, et al:: Osteogenesis imperfecta type $\mathrm{V}$ : marked phenotypic variability despite the presence of the IFITM5 c.-14C>T mutation in all patients. J Med Genet. 2013; 50(1): 21-4 PubMed Abstract | Publisher Full Text | F1000 Recommendation

43. F Becker J, Semler O, Gilissen C, et al:: Exome sequencing identifies truncating mutations in human SERPINF1 in autosomal-recessive osteogenesis imperfecta. Am J Hum Genet. 2011; 88(3): 362-71. PubMed Abstract | Publisher Full Text | Free Full Text | F1000 Recommendation

44. Homan EP, Rauch F, Grafe I, et al.: Mutations in SERPINF1 cause osteogenesis imperfecta type VI. J Bone Miner Res. 2011; 26(12): 2798-803. PubMed Abstract | Publisher Full Text | Free Full Text

45. F Guillén-Navarro E, Ballesta-Martínez MJ, Valencia M, et al.: Two mutations in FITM5 causing distinct forms of osteogenesis imperfecta. Am J Med Genet $A$ 2014; 164A(5): 1136-42.

PubMed Abstract | Publisher Full Text | F1000 Recommendation

46. F Farber CR, Reich A, Barnes AM, et al:: A novel IFITM5 mutation in severe atypical osteogenesis imperfecta type $\mathrm{VI}$ impairs osteoblast production of pigment epithelium-derived factor. J Bone Miner Res. 2014; 29(6): 1402-11.

PubMed Abstract | Publisher Full Text | Free Full Text | F1000 Recommendation

47. Renaud A, Aucourt J, Weill J, et al:: Radiographic features of osteogenesis imperfecta. Insights imaging. 2013; 4(4): 417-29. PubMed Abstract | Publisher Full Text | Free Full Text

48. Kusumi K, Ayoob R, Bowden SA, et al.: Beneficial effects of intravenous pamidronate treatment in children with osteogenesis imperfecta under 24 months of age. J Bone Miner Metab. 2014.

PubMed Abstract | Publisher Full Text

49. Rauch F, Plotkin H, Zeitlin L, et al.: Bone mass, size, and density in children and adolescents with osteogenesis imperfecta: effect of intravenous pamidronate therapy. J Bone Miner Res. 2003; 18(4): 610-4. PubMed Abstract | Publisher Full Text

50. Rauch F, Tutlewski B, Schönau E, et al.: The bone behind a low areal bone mineral density: peripheral quantitative computed tomographic analysis in a woman with osteogenesis imperfecta. J Musculoskelet Neuronal Interact. 2002; 2(4): 306-8. PubMed Abstract

51. Jones SJ, Glorieux FH, Travers R, et al.: The microscopic structure of bone in normal children and patients with osteogenesis imperfecta: a survey using backscattered electron imaging. Calcif Tissue Int. 1999; 64(1): 8-17. PubMed Abstract | Publisher Full Text

52. Rauch F, Travers R, Parfitt AM, et al:: Static and dynamic bone histomorphometry in children with osteogenesis imperfecta. Bone. 2000; 26(6): 581-9. PubMed Abstract | Publisher Full Text

53. Roschger P, Fratzl-Zelman N, Misof BM, et al.: Evidence that abnormal high bone mineralization in growing children with osteogenesis imperfecta is not associated with specific collagen mutations. Calcif Tissue Int. 2008; 82(4): 263-70.

PubMed Abstract | Publisher Full Text

54. Pazzaglia UE, Congiu T, Brunelli PC, et al:: The long bone deformity of osteogenesis imperfecta III: analysis of structural changes carried out with scanning electron microscopic morphometry. Calcif Tissue Int. 2013; 93(5): 453-61.

PubMed Abstract | Publisher Full Text 
55. Albert C, Jameson J, Smith P, et al:: Reduced diaphyseal strength associated with high intracortical vascular porosity within long bones of children with osteogenesis imperfecta. Bone. 2014; 66: 121-30. PubMed Abstract | Publisher Full Text | Free Full Text

56. Vardakastani V, Saletti D, Skalli W, et al.: Increased intra-cortical porosity reduces bone stiffness and strength in pediatric patients with osteogenesis imperfecta. Bone. 2014; 69: 61-7.

PubMed Abstract | Publisher Full Text

57. Jameson JR, Albert Cl, Busse B, et al.: 3D micron-scale imaging of the cortical bone canal network in human osteogenesis imperfecta (OI). In Proceedings of SPIE, Medical Imaging 2013: Biomedical Applications in Molecular, Structural, and Functional Imaging. JB Weaver and RC Molthen, Editors. 2013, International Society for Optics and Photonics: Lake Buena Vista, FL. 2013; 8672. Publisher Full Text

58. Wenstrup RJ, Willing MC, Starman BJ, et al.: Distinct biochemical phenotypes predict clinical severity in nonlethal variants of osteogenesis imperfecta. Am J Hum Genet. 1990; 46(5): 975-82. PubMed Abstract | Free Full Text

59. Byers $\mathrm{PH}$, Wallis GA, Willing MC: Osteogenesis imperfecta: translation of mutation to phenotype. J Med Genet. 1991; 28(7): 433-42. PubMed Abstract | Publisher Full Text | Free Full Text

60. Marini JC, Forlino A, Cabral WA, et al:: Consortium for osteogenesis imperfecta mutations in the helical domain of type I collagen: regions rich in lethal mutations align with collagen binding sites for integrins and proteoglycans. Hum Mutat. 2007; 28(3): 209-21.

PubMed Abstract | Publisher Full Text | Free Full Text

61. Barsh GS, David KE, Byers PH: Type I osteogenesis imperfecta: a nonfunctional allele for pro alpha 1 (I) chains of type I procollagen. Proc Natl Acad Sci U S A. 1982; 79(12): 3838-42.

PubMed Abstract | Publisher Full Text | Free Full Text

62. Sykes B, Francis MJ, Smith R: Altered relation of two collagen types in osteogenesis imperfecta. N Engl J Med. 1977; 296(21): 1200-3. PubMed Abstract | Publisher Full Text

63. Willing MC, Deschenes SP, Scott DA, et al:: Osteogenesis imperfecta type I: molecular heterogeneity for COL1A1 null alleles of type I collagen. Am J Hum Genet. 1994; 55(4): 638-47. PubMed Abstract | Free Full Text

64. Shapiro JR: Clinical and genetic classification of osteogenesis imperfecta and epidemiology. In Osteogenesis imperfecta - a translational approach to brittle bon disease. JR Shapiro, et al., Editors. Academic Press: San Diego, CA. 2014: 15-22. Publisher Full Text

65. Cassella JP, Ali SY: Abnormal collagen and mineral formation in osteogenesis imperfecta. Bone Miner. 1992; 17(2): 123-8. PubMed Abstract | Publisher Full Text

66. Cassella JP, Barber P, Catterall AC, et al:: A morphometric analysis of osteoid collagen fibril diameter in osteogenesis imperfecta. Bone. 1994; 15(3): 329-34. PubMed Abstract | Publisher Full Text

67. Stöss $\mathrm{H}$, Freisinger $\mathrm{P}$ : Collagen fibrils of osteoid in osteogenesis imperfecta: morphometrical analysis of the fibril diameter. Am J Med Genet. 1993; 45(2): 257.

PubMed Abstract | Publisher Full Text

68. Vetter U, Eanes ED, Kopp JB, et al.: Changes in apatite crystal size in bones of patients with osteogenesis imperfecta. Calcif Tissue Int. 1991; 49(4): 248-50. PubMed Abstract | Publisher Full Text

69. Traub W, Arad T, Vetter U, et al:: Ultrastructural studies of bones from patients with osteogenesis imperfecta. Matrix Biol. 1994; 14(4): 337-45.

PubMed Abstract | Publisher Full Text

70. Fratzl-Zelman $\mathrm{N}$, Schmidt I, Roschger $\mathrm{P}$, et al:: Unique micro- and nano-scale mineralization pattern of human osteogenesis imperfecta type VI bone. Bone. 2015; 73: 233-41.

PubMed Abstract | Publisher Full Text

71. Kozloff KM, Carden A, Bergwitz C, et al.: Brittle IV mouse model for osteogenesis imperfecta IV demonstrates postpubertal adaptations to improve whole bone strength. J Bone Miner Res. 2004; 19(4): 614-22. PubMed Abstract | Publisher Full Text

72. Jepsen $\mathrm{KJ}$, Schaffler MB, Kuhn JL, et al:: Type I collagen mutation alters the strength and fatigue behavior of Mov13 cortical tissue. J Biomech. 1997; 30(11-12): 1141-7

PubMed Abstract | Publisher Full Tex

73. McCarthy EA, Raggio CL, Hossack MD, et al.: Alendronate treatment for infants with osteogenesis imperfecta: demonstration of efficacy in a mouse model. Pediatr Res. 2002; 52(5): 660-70. PubMed Abstract | Publisher Full Text

74. Misof BM, Roschger P, Baldini T, et al:: Differential effects of alendronate treatment on bone from growing osteogenesis imperfecta and wild-type mouse. Bone. 2005; 36(1): 150-8. PubMed Abstract | Publisher Full Tex

75. Miller E, Delos D, Baldini T, et al:: Abnormal mineral-matrix interactions are a significant contributor to fragility in oim/oim bone. Calcif Tissue Int. 2007; 81(3): 206-14.

PubMed Abstract | Publisher Full Text | Free Full Text
76. Rao SH, Evans KD, Oberbauer AM, et al:: Bisphosphonate treatment in the oim mouse model alters bone modeling during growth. J Biomech. 2008; 41(16): 3371-6.

PubMed Abstract | Publisher Full Text | Free Full Text

77. Albert C, Jameson J, Toth JM, et al.: Bone properties by nanoindentation in mild and severe osteogenesis imperfecta. Clin Biomech (Bristol, Avon). 2013; 28(1): 110-6.

PubMed Abstract | Publisher Full Text

78. Fan Z, Smith PA, Harris GF, et al:: Comparison of nanoindentation measurements between osteogenesis imperfecta Type III and Type IV and between different anatomic locations (femur/tibia versus iliac crest). Connect Tissue Res. 2007; 48(2): 70-5.

PubMed Abstract | Publisher Full Text

79. Weber M, Roschger P, Fratzl-Zelman N, et al.: Pamidronate does not adversely affect bone intrinsic material properties in children with osteogenesis imperfecta. Bone. 2006; 39(3): 616-22.

PubMed Abstract | Publisher Full Text

80. Imbert L, Aurégan J, Pernelle K, et al:: Mechanical and mineral properties of osteogenesis imperfecta human bones at the tissue level. Bone. 2014; 65 18-24.

PubMed Abstract | Publisher Full Text

81. Albert $\mathrm{Cl}$, Jameson J, Harris G: Design and validation of bending test method for characterization of miniature pediatric cortical bone specimens. Proc Inst Mech Eng H. 2013; 227(2): 105-13.

PubMed Abstract | Publisher Full Text

82. Fritz JM, Grosland NM, Smith PA, et al.: Brittle bone fracture risk with transverse isotropy. In Proceedings of the 37th Annual Meeting of the American Society of Biomechanics. September 4-7. Omaha, NE, 2013.

Reference Source

83. Boyd SK, Müller R: Smooth surface meshing for automated finite element model generation from 3D image data. J Biomech. 2006; 39(7): 1287-95. PubMed Abstract | Publisher Full Text

84. Shim VB, Pitto RP, Streicher RM, et al:: The use of sparse CT datasets for auto-generating accurate FE models of the femur and pelvis. $J$ Biomech. 2007 ; 40(1): 26-35.

PubMed Abstract | Publisher Full Text

85. Edwards WB, Troy KL: Simulating distal radius fracture strength using biomechanical tests: a modeling study examining the influence of boundary conditions. J Biomech Eng. 2011; 133(11): 114501.

PubMed Abstract | Publisher Full Text

86. Edwards WB, Troy KL: Finite element prediction of surface strain and fracture strength at the distal radius. Med Eng Phys. 2012; 34(3): 290-8.

PubMed Abstract | Publisher Full Text

87. Fritz JM, Guan $\mathrm{Y}$, Wang $\mathrm{M}$, et al:: A fracture risk assessment model of the femur in children with osteogenesis imperfecta (OI) during gait. Med Eng Phys. 2009; 31(9): 1043-8.

PubMed Abstract | Publisher Full Text

88. Fritz JM, Guan $\mathrm{Y}$, Wang M, et al:: Muscle force sensitivity of a finite element fracture risk assessment model in osteogenesis imperfecta - biomed 2009 Biomed Sci Instrum. 2009; 45: 316-21.

PubMed Abstract

89. F Orwoll ES, Shapiro J, Veith S, et al.: Evaluation of teriparatide treatment in adults with osteogenesis imperfecta. J Clin Invest. 2014; 124(2): 491-8. PubMed Abstract | Publisher Full Text | Free Full Text | F1000 Recommendation

90. F Caouette $\mathrm{C}$, Rauch $\mathrm{F}$, Villemure I, et al.: Biomechanical analysis of fracture isk associated with tibia deformity in children with osteogenesis imperfecta: a finite element analysis. J Musculoskelet Neuronal Interact. 2014; 14(2): 205-12. PubMed Abstract | F1000 Recommendation

91. F Hoyer-Kuhn H, Semler O, Stark C, et al: A specialized rehabilitation approach improves mobility in children with osteogenesis imperfecta. J Musculoskelet Neuronal Interact. 2014; 14(4): 445-53. PubMed Abstract | F1000 Recommendation

92. Licata AA: Discovery, clinical development, and therapeutic uses of bisphosphonates. Ann Pharmacother. 2005; 39(4): 668-77. PubMed Abstract | Publisher Full Text

93. Rauch F, Travers $\mathrm{R}$, Plotkin $\mathrm{H}$, et al:: The effects of intravenous pamidronate on the bone tissue of children and adolescents with osteogenesis imperfecta. J Clin Invest. 2002; 110(9): 1293-9. PubMed Abstract | Publisher Full Text | Free Full Text

94. Plotkin H, Rauch F, Bishop NJ, et al.: Pamidronate treatment of severe osteogenesis imperfecta in children under 3 years of age. $J$ Clin Endocrinol Metab. 2000; 85(5): 1846-50.

PubMed Abstract | Publisher Full Text

95. Land C, Rauch F, Munns CF, et al.: Vertebral morphometry in children and adolescents with osteogenesis imperfecta: effect of intravenous pamidronate treatment. Bone. 2006; 39(4): 901-6. PubMed Abstract | Publisher Full Text

96. F Bishop N, Adami S, Ahmed SF, et al:: Risedronate in children with osteogenesis imperfecta: a randomised, double-blind, placebo-controlled trial. Lancet. 2013; 382(9902): 1424-32.

PubMed Abstract | Publisher Full Text | F1000 Recommendation 
97. Nicolaou N, Agrawal $\mathrm{Y}$, Padman M, et al.: Changing pattern of femoral fractures in osteogenesis imperfecta with prolonged use of bisphosphonates. $J$ Child Orthop. 2012; 6(1): 21-7.

PubMed Abstract | Publisher Full Text | Free Full Text

98. Carpintero P, Del Fresno JA, Ruiz-Sanz J, et al:: Atypical fracture in a child with osteogenesis imperfecta. Joint Bone Spine. 2015; 82(4): 287-8. PubMed Abstract | Publisher Full Text

99. Malmgren B, Aström E, Söderhäll S: No osteonecrosis in jaws of young patients with osteogenesis imperfecta treated with bisphosphonates. J Oral Pathol Med. 2008; 37(4): 196-200

PubMed Abstract | Publisher Full Text

100. Chahine C, Cheung MS, Head TW, et al.: Tooth extraction socket healing in pediatric patients treated with intravenous pamidronate. J Pediatr. 2008; 153(5): 719-20.

PubMed Abstract | Publisher Full Text

101. Hennedige AA, Jayasinghe J, Khajeh J, et al: Systematic review on the incidence of bisphosphonate related osteonecrosis of the jaw in children diagnosed with osteogenesis imperfecta. J Oral Maxillofac Res. 2014; 4(4): e1. PubMed Abstract | Free Full Text

102. Adami S, Gatti D, Colapietro F, et al:: Intravenous neridronate in adults with osteogenesis imperfecta. J Bone Miner Res. 2003; 18(1): 126-30. PubMed Abstract | Publisher Full Text

103. Chevrel G, Schott AM, Fontanges E, et al.: Effects of oral alendronate on BMD in adult patients with osteogenesis imperfecta: a 3-year randomized placebo-controlled trial. J Bone Miner Res. 2006; 21(2): 300-6. PubMed Abstract | Publisher Full Text

104. Shapiro JR, Thompson $\mathrm{CB}, \mathrm{Wu} \mathrm{Y}$, et al:: Bone mineral density and fracture rate in response to intravenous and oral bisphosphonates in adult osteogenesis imperfecta. Calcif Tissue Int. 2010; 87(2): 120-9. PubMed Abstract | Publisher Full Text

105. Bradbury LA, Barlow S, Geoghegan F, et al.: Risedronate in adults with osteogenesis imperfecta type I: increased bone mineral density and decreased bone turnover, but high fracture rate persists. Osteoporos Int. 2012; 23(1): 285-94. PubMed Abstract | Publisher Full Text

106. O'Sullivan ES, van der Kamp S, Kilbane M, et al:: Osteogenesis imperfecta in adults: phenotypic characteristics and response to treatment in an Irish cohort. Ir J Med Sci. 2014; 183(2): 225-30. PubMed Abstract | Publisher Full Text

107. F Phillipi CA, Remmington T, Steiner RD: Bisphosphonate therapy for osteogenesis imperfecta. Cochrane Database Syst Rev. 2008; (4): CD005088. PubMed Abstract | Publisher Full Text | F1000 Recommendation

108. F Hald JD, Evangelou E, Langdahl BL, et al.: Bisphosphonates for the prevention of fractures in osteogenesis imperfecta: meta-analysis of placebo-controlled trials. J Bone Miner Res. 2015; 30(5): 929-33. PubMed Abstract | Publisher Full Text | F1000 Recommendation

109. F Antoniazzi F, Monti E, Venturi G, et al:: $\mathrm{GH}$ in combination with isphosphonate treatment in osteogenesis imperfecta. Eur J Endocrinol. 2010; 163(3): 479-87.

PubMed Abstract | Publisher Full Text | F1000 Recommendation

110. Neer RM, Arnaud CD, Zanchetta JR, et al:: Effect of parathyroid hormone (1-34) on fractures and bone mineral density in postmenopausal women with osteoporosis. N Engl J Med. 2001; 344(19): 1434-41. PubMed Abstract | Publisher Full Text

111. F Gatti D, Rossini M, Viapiana $O$, et al.: Teriparatide treatment in adult patients with osteogenesis imperfecta type I. Calcif Tissue Int. 2013; 93(5): 448-52. PubMed Abstract | Publisher Full Text | F1000 Recommendation
112. F Cummings SR, San Martin J, McClung MR, et al.: Denosumab for prevention of fractures in postmenopausal women with osteoporosis. N Engl J Med. 2009; 361(8): 756-65.

PubMed Abstract | Publisher Full Text | F1000 Recommendation

113. F Hoyer-Kuhn $\mathrm{H}$, Netzer $\mathrm{C}$, Koerber $\mathrm{F}$, et al.: Two years' experience with denosumab for children with osteogenesis imperfecta type VI. Orphanet $J$ Rare Dis. 2014; 9: 145.

PubMed Abstract | Publisher Full Text | Free Full Text | F1000 Recommendation

114. Hoyer-Kuhn H, Semler O, Schoenau E: Effect of denosumab on the growing keleton in osteogenesis imperfecta. J Clin Endocrinol Metab. 2014; 99(11): 3954-5.

PubMed Abstract | Publisher Full Text

115. Boyce AM, Chong WH, Yao J, et al:: Denosumab treatment for fibrous dysplasia J Bone Miner Res. 2012; 27(7): 1462-70. PubMed Abstract | Publisher Full Text | Free Full Text

116. F McClung MR, Grauer A, Boonen S, et al.: Romosozumab in postmenopausal women with low bone mineral density. N Engl J Med. 2014; 370(5): 412-20. PubMed Abstract | Publisher Full Text | F1000 Recommendation

117. F Sinder BP, Eddy MM, Ominsky MS, et al.: Sclerostin antibody improves skeletal parameters in a Brtl/+ mouse model of osteogenesis imperfecta. J Bone Miner Res. 2013; 28(1): 73-80.

PubMed Abstract | Publisher Full Text | Free Full Text | F1000 Recommendation

118. F Sinder BP, White LE, Salemi JD, et al:: Adult Brtl/+ mouse model of osteogenesis imperfecta demonstrates anabolic response to sclerostin antibody treatment with increased bone mass and strength. Osteoporos Int 2014; 25(8): 2097-107.

PubMed Abstract | Publisher Full Text | Free Full Text | F1000 Recommendation

119. $F$ Roschger $A$, Roschger $P$, Keplingter $P$, et al.: Effect of sclerostin antibody reatment in a mouse model of severe osteogenesis imperfecta. Bone. 2014; 66: $182-8$.

PubMed Abstract | Publisher Full Text | F1000 Recommendation

120. F Grafe I, Yang T, Alexander S, et al.: Excessive transforming growth factor- $\beta$ signaling is a common mechanism in osteogenesis imperfecta. Nat Med. 2014; 20(6): 670-5.

PubMed Abstract | Publisher Full Text | Free Full Text | F1000 Recommendation

121. Horwitz EM, Prockop DJ, Gordon PL, et al.: Clinical responses to bone marrow transplantation in children with severe osteogenesis imperfecta. Blood. 2001; 97(5): 1227-31.

PubMed Abstract | Publisher Full Text

122. F Horwitz EM, Gordon PL, Koo WK, et al:: Isolated allogeneic bone marrow-derived mesenchymal cells engraft and stimulate growth in children with osteogenesis imperfecta: Implications for cell therapy of bone. Proc Nath Acad Sci U S A. 2002; 99(13): 8932-7.

PubMed Abstract | Publisher Full Text | Free Full Text | F1000 Recommendation

123. F Le Blanc K, Götherström C, Ringdén O, et al:: Fetal mesenchymal stem-cell engraftment in bone after in utero transplantation in a patient with severe osteogenesis imperfecta. Transplantation. 2005; 79(11): 1607-14. PubMed Abstract | Publisher Full Text | F1000 Recommendation

124. Amin MT, Shazly SA: In utero stem cell transplantation for radical treatment of osteogenesis imperfecta: perspectives and controversies. Am J Perinatol. 2014 31(10): 829-36.

PubMed Abstract | Publisher Full Text

125. $\mathrm{F}$ Lindahl K, Kindmark A, Laxman N, et al.: Allele dependent silencing of collagen type I using small interfering RNAs targeting 3'UTR Indels - a novel therapeutic approach in osteogenesis imperfecta. Int J Med Sci. 2013; 10(10): 1333-43

PubMed Abstract | Publisher Full Text | Free Full Text | F1000 Recommendation 


\section{Open Peer Review}

\section{Current Peer Review Status:}

\section{Version 1}

Reviewer Report 07 September 2015

https://doi.org/10.5256/f1000research.6864.r10219

(c) 2015 Clarke B. This is an open access peer review report distributed under the terms of the Creative Commons Attribution License, which permits unrestricted use, distribution, and reproduction in any medium, provided the original work is properly cited.

\section{Bart Clarke}

Division of Endocrinology, Diabetes, Metabolism, and Nutrition, Mayo Clinic College of Medicine, Rochester, MN, USA

Competing Interests: No competing interests were disclosed.

I confirm that I have read this submission and believe that I have an appropriate level of expertise to confirm that it is of an acceptable scientific standard.

Reviewer Report 07 September 2015

https://doi.org/10.5256/f1000research.6864.r10218

(C) 2015 Rao S. This is an open access peer review report distributed under the terms of the Creative Commons Attribution License, which permits unrestricted use, distribution, and reproduction in any medium, provided the original work is properly cited.

\section{Sudhaker Dhanwada Rao}

Division of Endocrinology, Diabetes and Bone \& Mineral Disorders, Henry Ford Hospital, Detroit, MI, USA

Competing Interests: No competing interests were disclosed.

I confirm that I have read this submission and believe that I have an appropriate level of expertise to confirm that it is of an acceptable scientific standard.

Reviewer Report 07 September 2015 


\section{https://doi.org/10.5256/f1000research.6864.r10217}

(C) 2015 McKenna M. This is an open access peer review report distributed under the terms of the Creative Commons Attribution License, which permits unrestricted use, distribution, and reproduction in any medium, provided the original work is properly cited.

Malachi J. McKenna

St. Vincent's University Hospital, Dublin, Ireland

Competing Interests: No competing interests were disclosed.

I confirm that I have read this submission and believe that I have an appropriate level of expertise to confirm that it is of an acceptable scientific standard.

\section{Comments on this article}

\section{Version 1}

Reader Comment 30 Sep 2015

Raymond Dalgleish, University of Leicester, UK

I have noted a few issues in this article:

1. On page 2, in the section headed "Genes and classification", gene symbols (COLIA1 and COL1A2) are inappropriately used to designate the component protein chains of type I collagen. Gene symbols and protein product names should not be used interchangeably. The protein chains are a1(I) and a2(I) respectively.

2. In Table 1, the gene symbols for the mutant genes leading to OI types I, II, III and IV are incorrect. They should be COL1A1 and COL1A2, not COL1A1 and COLA2.

3. In Table 1, the gene symbol for the gene encoding the protein prolyl-3 hydroxylase is $\mathrm{P} 3 \mathrm{H} 1$, not LEPRE1. The gene symbol for this gene was changed to P3H1 in December 2014.

4. Table 1 continues to propagate the notion that there are very many OI types when, in reality, there are really only five true types which can be clearly distinguished clinically (types I to V). The problem has been caused by several new OI types being created to correspond to newly discovered genes which harbour OI-causing sequence variants. This has only served to confuse matters and is discussed at length by Van Dijk and Sillence (2014) ( http://www.ncbi.nlm.nih.gov/pubmed/24715559).

5. It is perhaps unsurprising that the article gives emphasis to pharmacological interventions for OI, given that one of the authors is employed by Alexion Pharmaceuticals, but it is improper to ignore surgical interventions such as rodding of long bones and mesenchymal stem cell therapy.

6. There is no mention in the article of the fact that there is a comprehensive database of gene variants leading to OI: https://oi.gene.le.ac.uk/. 
7. The list of OI genes is incomplete in Table 1. A comprehensive list of genes may be found at https://oi.gene.le.ac.uk/status.php.

Competing Interests: I declare that I curate the database of OI gene variants which in mentioned in comment 6.

The benefits of publishing with F1000Research:

- Your article is published within days, with no editorial bias

- You can publish traditional articles, null/negative results, case reports, data notes and more

- The peer review process is transparent and collaborative

- Your article is indexed in PubMed after passing peer review

- Dedicated customer support at every stage

For pre-submission enquiries, contact research@f1000.com 